\title{
After the riot? Rancière, Hamilton, and radical politics
}

\author{
Laurence Piper
}

\begin{abstract}
In recent years, political forces from the Occupy movement in North America to the \#FeesMustFall student protest in South Africa have attempted to disrupt the political order in the name of democratic equality. Inspired by radical theorists like Rancière, this politics promises a model of social change through the combination of the disruption of institutions and the reinvention of daily life and political subjectivities. I argue that this radical politics comes with significant limits if it ignores the requirement to build more inclusive policies and new institutions too. This is because disruption alone may extend exclusion by prompting more elite coercion and popular backlash. This claim is illustrated through the example of the \#FeesMustFall movement. What is needed instead is a radical politics that also includes a clear theoretical focus on policy and institutional change, such as is contained in Hamilton's account of freedom as power through representation.
\end{abstract}

\section{Introduction}

Recent years have seen the rise of radical political philosophy associated with names like Cavell, Žižek, and Rancière that has come to replace the debates at the turn of the century between what Žižek describes as traditionalist communitarians (Taylor), modern universalists (Habermas and Rawls), and postmodern dispersionists (Lyotard). ${ }^{1}$ Criticizing these approaches for reducing the political in favor of some account of pre-political ethics, Žižek, and more radical scholars like Rancière place politics at the center of their thought, especially some version of dissensus with, or disruption of, normal politics and/or the transgression of mainstream identities and political subjectivities. Key to the growing reception of these thinkers is not just the force of their ideas but also the resonance of this politics with emergent left political practice around the world, especially in the Occupy movement and, more recently, in South Africa in the \#FeesMustFall protests on university campuses.

In this article I engage with what I think is the key weakness of radical politics as political action at the expense of a vision of policy and institutional change. My key concern is how this politics, decoupled from policy and institutional vision, can further enable new forms of oppression, exclusion, and marginalization in reaction to dissent, a possibility evident now in Trump's America and Brexit Britain, but long present in the Global South where democratic institutions and policies of social inclusion are more vulnerable to contestation. Indeed, there is much experience across the postcolonial world of the negative consequences of disrupting budding democratic institutions and policies, whether externally backed assassinations or coups, such as Lumumba in Zaire or Allende in Chile, or the capture of the state by predatory 
elites in response to political crises in democracies (Thailand, Egypt, Mali), sometimes even with majority popular support, as in Turkey currently.

In making this case I contrast the theoretical arguments of Jacques Rancière with those of the republican thinker Lawrence Hamilton, illustrating my claims through the example of the \#FeesMustFall movement in South Africa. While Rancière is a clear exemplar of current radical political philosophy, Hamilton is less known, but a good object of comparison as he shares the radical political philosophical focus on politics over ethics and also embraces an aesthetic account of representation that echoes Rancière's aesthetic account of politics. Notably, however, where Rancière begins his political analysis from an assumption of democracy as radical equality, Hamilton follows more Foucault's argument about the inevitability of power relations between groups, and focuses on the republican concern on preventing power relations as domination. These diverse idealist versus realist starting points generate significantly different implications for political practice. Rancière's approach emphasizes the primacy of political action to disrupt the political system in the name of radical equality, whereas Hamilton's emphasizes more thinking through the policy and institutional alternatives that such action must produce to enhance collective freedom.

While criticized for a lack of an explicit focus on politics in his work to date, I argue that Hamilton's theory offers more by way of resources to secure sustainable social change for radical political practitioners than Rancière's. This is because Hamilton's theory forces us to think through the new forms of power desired after the riot, given the inevitable nature of power relations between groups, as well as offering an argument as to the conditions of freedom that need to be encoded in new institutions. Despite attempts by some like Norval to read into Rancière a more substantial politics through the notion of an ethos of inscription, ${ }^{2}$ because of his profoundly normative starting point of democracy as radical equality Rancière remains too skeptical of the "police" to enable much practical politics other than disruption. Conversely, while Hamilton has yet to write explicitly about political action, I would suggest that inherent in his account are some key assumptions that would inform a real-world politics for freedom.

This case is illustrated through the example of the \#FeesMustFall movement that secured significant material and symbolic victories in the last few years, and which can also be framed in terms of a Rancièrian politics of disruption. Notably, however, \#FeesMustFall remains a movement rather than an organization, and has failed to develop a substantial alternative policy and institutional vision, especially around student governance on campuses. This leaves the political party capture of student representation on South African campuses largely unchallenged, and \#FeesMustFall without many natural allies among more moderate students and staff. Thus going forward it looks likely that not only might free higher education not be achieved, but the conditions for free student voice on campuses might be further constricted, and \#FeesMustFall will be increasingly vulnerable to repression. 


\section{Rancière, "Politics," and the "Police"}

Rancière's political philosophy starts from the assumption of democracy as radical equality as "there is no natural principle of domination by one person over another."3 This principle serves as the radical point of critique of any self-proclaimed democracy that establishes a power hierarchy or inequality in power relations. Indeed, this principle forms the foundation of the distinction in Rancière's thought between "politics" and the "police." The latter, the "police", refers to the totality of the social order, inclusive of everyone, all places and institutions. It is broader than the state, includes economic and social relations, and is a power hierarchy with a well-known and legitimated "distribution of the sensible." 4 This refers to a widely acknowledged and embraced view of the social order (what others might term the hegemonic worldview) that effectively limits what we term politics to problems of power and wealth in predefined social domains.

For Rancière, however, real politics is the disruption of this commonly held "distribution of the sensible" and the domain of the police in the name of radical equality by "a part of those who have no part," that is those who are unknown and marginalized from the "distribution of the sensible." 5 Importantly for Rancière, the "part that has no part" are not known or named before the act of disruption; it is only in the process of coming to political consciousness and naming themselves that the "part that has no part" comes to have a name. Thus, political dissensus extends not just to the act of disrupting existing institutions and practices but also to challenging the symbolic order. For Rancière then, real politics is not the clash between named groups, but when those unimagined by the social order disrupt its basic logic. It thus involves a deeper clash between "police" logic and egalitarian logic. At the same time, it is about constructing new political subjectivities through this process and thus requires a moment of "dis-identification" with the existing order and the establishment of a new name not recognized by the order through the process of collective action. Real politics is thus about a fundamental dissensus, not regular and recognizable conflict. It may well be uncommon, but can happen anywhere where rejection of the "police hierarchy" in the name of radical equality occurs.

Perhaps because real politics cannot occur outside the "police," as no place exists, Rancière characterizes the spaces of politics as "in-between spaces," or "intervals of subjectification," "constructed between identities, between spaces and places." Thus "political being-together is being-between: between identities, between worlds." 6 Notably, these spaces do no preexist the political but are created through it. In this regard, Bassett notes that Rancière is very critical of Marxism, which he sees as defining the truth about politics (economic relations) as outside the political process itself, and rejects any grand postcapitalist vision in favor of those "communist moments"-when workers succeeded, however locally and fleetingly, in collectivizing the power of anyone with everyone.7

Thus, while Rancière explicitly eschews any reflection on postcapitalist institutions or what an egalitarian future might look like, Basset argues that he stands close to the interstitial politics of certain kinds of anarchism that "attempt to build alternatives to capitalism . . . by 
operating in the cracks and spaces within dominant structures of power." 8 However, it is not a form of politics that affirms the local communitarianism of some kinds of anarchism, as it always returns to the fundamental principle of radical equality in governance. 9

Although by now it is clear that, as Norval characterizes it, Rancière's view of democracy is one of rupture rather than the rival view of democracy as routinized change, she nevertheless argues that there is more to his politics than disruption. ${ }^{10}$ While noting that Rancière is deeply suspicious of inscription leading to inclusion into some form of the "police," thus violating the principle of radical equality, Norval argues for an ethos of egalitarian inscription that can be derived from Rancière's writings. Based on exemplars that bridge disruption and inscription in his historical work, Norval suggests that a Rancièrian-style inscription would include: the declaration of wrong including "the naming of hitherto unnamed subjects," "the reclaiming of a given name," "the staging of a wrong that seeks to reconfigure the sensible," "the imagining of other possibilities," and "and seeing the universal in the singular."11

In short, however, even on the most generous readings by Basset and Norval, what remains for Rancière after the riot is at best an ethos with which to approach inscription, but one grounded in a rejection of any reform that inscribes new forms of hierarchy in violation of radical equality. This is a view of politics as constant disruption of the "police" rather than of one of incremental change or institutional reform. It is, however, a kind of politics that is both possible and even affective as demonstrated in the following account of the \#FeesMustFall movement in South Africa.

\section{Rancière and \#FeesMustFall}

In what follows I will outline my reading of the \#FeesMustFall politics over the last three years, particularly in the campus on which I work, identifying some remarkable resonances with Rancière's account of politics and the police. Importantly, this is not an analysis based on the self-understanding(s) of the \#FeesMustFall movement, nor an attempt to impose a Rancièrian frame on this politics in order to claim deeper understanding of \#FeesMustFall. Rather, the \#FeesMustFall case is used to illustrate larger claims about the strength and weaknesses of competing accounts of radical politics found in Rancière and Hamilton, especially in the developing world. These points are critical to make in a South African context where the decolonization of intellectual life is currently a leading debate. Indeed, my argument is intended to contribute to this debate by demonstrating the costs of an uncritical importation of radical philosophical thought in conditions common across the Global South.

The \#FeesMustFall movement began in 2015 as a student movement mostly about free higher education. The issue of fees and the financial exclusion of poor students has been an issue on the higher education landscape in South Africa since 1994, but has grown in significance with the relative decline in state support for higher education, an economic downturn, and increasing numbers of poor students finding their way to university. These 
material conditions saw the proposed increase in fees by universities met with protest that was quickly nationalized in 2015. As suggested by the hashtag identity of \#FeesMustFall, social media was a key instrument in the spread of the protest, and indeed, there are many more hashtags, both nationally (\#FreeEducation) and on each campus (\#RhodesMustFall, \#UWCFeesMustFall) and by year (\#FeesMustFall2016). For the purposes of this article, I will use \#FeesMustFall to represent all of these.

Notably, the initiative for \#FeesMustFall started at the Universities of Cape Town, Johannesburg, and Rhodes, three of the original eight historically white Universities under apartheid, but extended across most of the 26 universities in the country. In addition to free education, demands included the racial transformation of staff and student bodies, the decolonization of the Western knowledge inherent in higher education, the insourcing of university workers, removing private security and the police from campuses, as well as a range of local issues from residence conditions to library hours, Internet access, and the like. The ensuing negotiations between students and university administration dragged on with little progress while protest escalated, leading to the disruption of classes, protest marches to parliament in Cape Town and the ANC head office in Johannesburg. Events culminated in a march on the home of government, the Union Buildings in Pretoria, in October 2015, where President Zuma announced there would be no increase in fees for 2016.

Marred by a series of violent confrontations, the march on the Union Buildings effectively marked the end of \#FeesMustFall until the following year, when the pattern repeated itself as universities announced various fee increases for 2017. While protest and confrontation did not reach quite the same levels as in 2016, there were many instances of violent conflict between police and protestors, and by the end of the year government announced that it would subside university increases of up to 8 percent, effectively maintaining a o percent increase again as universities did not go past the 8 percent mark. In addition, many historically white universities have embarked on attempts to accelerate the racial transformation of the staff profile, and are engaging in efforts to decolonize the curriculum. For many academics, including myself, the intellectual challenge posed by the call for the decolonization of knowledge has been an important and transformative one.

Despite these gains, by the end of 2016 the \#FeesMustFall movement was beginning to show significant cracks, not least as following the march to Union Building in 2015, the leading national student organization, SASCO (South African Students Congress), came under pressure from the ruling party, the African National Congress (ANC), to which it is aligned, to demobilize protest. On some campuses, such as the one on which I work, this led to split in the \#FeesMustFall movement between the Student Representative Council (SRC), the elected representative structure for students controlled by SASCO, and others in the movement. This tension endured into 2016, undermining the common ground for student mobilization, and leading to more radical elements taking a leading role in the movement-at least on my campus. ${ }^{12}$ While different dynamics were manifest on different campuses around the country, a general trend was an emerging party political influence in 2016, where \#FeesMustFall was 
increasingly associated with anti-ANC political parties such as the Economic Freedom Fighters (EFF) and the Pan Africanist Congress (PAC).

To my mind the rise of partisan politics and its polarizing effect on the \#FeesMustFall movement is actually a return to what Rancière would term the "police" order of higher education institutions, as student representation on almost every campus across the country is dominated by political parties. As is the case more widely in Africa, 13 student politics is as much a training ground for aspirant politicians, both ANC and opposition political parties, as it is a forum for student voice. Not only are most candidates for office from campus branches of political parties, but also on campuses like the one I work on, the electoral system is a proportional representation party-list system. Students do not vote for candidates but political parties, and the parties choose the student representatives. ${ }^{14}$ As is widely observed, the proportional representation system comes with significant accountability deficits, as representatives' account to the party not to the electorate. 15 Thus party identification allows student leaders access to political identities and ideologies readily identifiable by students but comes with the risk of orientation to national issues and party interests rather than local student concerns. Much of the time this is probably not a significant risk-until national political party and student interests' conflict as with the \# FeesMustFall movement.

Hopefully by now it is clear how the \#FeesMustFall movement can be framed in terms of a radical politics based on disruption in the name of radical equality. This is evident in \#FeesMustFall's egalitarian demands, its confrontational style, and its constitution as a movement rather than an organization. Thus, partly to avoid repression, ${ }^{16}$ but partly also to give expression to notions of radical equality, \#FeesMustFall has pursued decision-making through public meetings and through different leaders, some elected at meetings, some not, who engage with the university administration at different times. \#FeesMustFall's great strength in conceiving itself as a movement and not an organization is that it can be invoked by any group of students large enough to mobilize in its name. This gives it an organic but nonstructured character that means it struggles to engage in any forum other than the protest or the mass meeting. Thus \#FeesMustFall has refused to stand for student office and it lacks a clear internal organizational structure and hierarchy.

If so inclined, one could read into the practice of \#FeesMustFall many of the features of Rancièrian politics, especially the confrontation of the logic of the "police" with demands for radical equality. In addition one could point to the tactics of disordering the university; disidentifying with formal student representation, party politics, and for many, the Mandela "rainbow nation" compromise of 1994. One could also point to \#FeesMustFall's nature as an "insubstantial community" that is, a collective but not a unity; the affirmation of the unpredictable subject in the style and symbolism of the movement; and the seeking for new imaginings of the university and the country. All of this exemplifies democracy as disruption, and arguably redeems it as a form of bringing significant social change, not least the effective o percent fee increases in student fees nationally over the last two years, but perhaps 
even more significantly the attempt by the higher education sector to engage the challenge of decolonizing its practices of teaching and researching.

At the same time however, \#FeesMustFall is a great example of the limitations of "democracy as disruption" in policy, institutional, and political terms. In policy terms, \#FeesMustFall has been reluctant to engage in debates about the practical mechanisms for the funding of higher education. Indeed it has also not undertaken to develop a substantive vision of what a transformed and decolonized university sector would look like, and while this is partly because decolonization is in significant part about building alternative forms of knowledge that do not yet exist, it is also because \#FeesMustFall is a movement rather than an organization. An ironic shortcoming of not being an organization, and the politics of democracy as disruption more widely, is the failure to engage specifically with the institutional design of student governance on campuses. This is critical as the very existence of \#FeesMustFall is a performative critique of the failure of formal representation to bring pro-student change, and a key reason for this is the capture of student representation by party politics. Thus not only is this capture not addressed by a failure to call for the reform of student representative institutions, but party influence over student politics may well help undermine the conditions for future mobilization and disruption on many university campuses. With most SRCs led by the ANC aligned SASCO (South African Students Congress), it is not hard to imagine an alliance between formal student leaders and university administrators as \#FeesMustFall popularity begins to wane.

This brings us to \#FeesMustFall's politics of disruption, which, while effective when able to mobilize enough students, has targeted universities mostly rather than the state, even though universities cannot meet the demands of the movement on their own. The consequence has been to divide the student body, many of whom wanted to finish the academic year and did not appreciate having classes disrupted through the threat of violence, and to alienate many academic and support staff who felt torn between a duty to students and the principle of free education. Indeed, free education is probably the one cause in South Africa that could have united the vast majority of people working in the sector had the politics of \#FeesMustFall not only been about disruption, but also about alliance-building. Thus while we can expect protest to continue in the name of free education in the near future, it seems likely that it will be increasingly the preserve of an extreme minority on campuses.

Lastly, this analysis of the efficacy of democratic politics as disruption by \#FeesMustFall echoes larger debates about models of social change in South African society. Steve Robins contrasts the "spectacular" politics of the Seskhona people's movement in Cape Town with the "slow activism" of the Social Justice Coalition (SJC). ${ }^{17}$ While both organizations are concerned with the plight of poor people in the city, especially as regards sanitation, Robins points to the limited dividends of spectacular politics alone. Thus, Seskhona secured great attention for the issue of sanitation by dumping human waste at the airport and "poo-flinging" at government buildings, but has no clear policy or institutional proposals; their confrontational approach was met with a backlash from officials who saw leaders convicted of the movement halted. ${ }^{18}$ 
Notably, key Seskhona leaders later joined their former enemy, the DA (Democratic Alliance) party, which rules the City of Cape Town. 19

By contrast, the Social Justice Coalition (SJC) combines spectacular politics of protest with other forms of activism, including building alliances with other rights-based organizations using the constitution and law to hold government accountable. Also important are its clear proposals for policy and institutional change to improve sanitation for the poor in Cape Town. This "slow activism" Robins observes has seen significant increases in budget expenditure and changes in practices by the city that benefit the poor, albeit incrementally. As Robins points out, this is a politics with a long history in South Africa, best represented in the united front presented against apartheid by unions and civil society formations in the late 1980s. Real change, he suggests, is better approached through this "slow activism" model.

\section{Hamilton, Power, and the Politics of Disruption}

My argument so far is that framing democracy as disruption alone, divorced from policy and institutional questions a la Rancière, amounts to a poor model for effective social change in the Global South. Indeed, under certain conditions disruptive politics might provoke reactions that make society more exclusionary and less democratic. Hopefully the case of \#FeesMustFall has illustrated both the strengths but also the weaknesses of a radical politics as only disruption or the spectacular. A better and more practical model is to link disruption to policy and institutional goals, as articulated in Robins's account of "slow activism"-notably, a long-standing tradition in popular politics in South Africa. In addition to prudential grounds, however, there are good theoretical grounds for preferring slow activism to spectacular politics-and grounds that do not jettison the idea of the dissensus. For these it is to Lawrence Hamilton that I turn.

In his 2015 book, Freedom Is Power, Lawrence Hamilton offers a theory of freedom that shares the agonistic assumptions of radical theorists but locates this in a realist empirical account of power and politics inspired by Machiavelli. Thus unlike Rancière, who begins with the normative assumption of democracy as radical equality, Hamilton begins with the realistic account of modern society as characterized by a deep division of labor under some version of liberal-democratic capitalism. This gives rise to attendant power relations that define various groups, usually with contending understandings of their interests. Consequently, politics has a group character as power relations are understood to shape patterns of inclusion and exclusion; it is contentious, as groups often understand themselves as having competing interests or identities; and it necessarily involves an element of representation given the self-understanding of society as comprised of contending groups.

Unlike Rancière, who is focused on the ideal of democratic equality to which no version of the "police" can give full expression, Hamilton is inspired by the republican concern with ending domination and the inevitability of some unequal relations of power. He is, however, more ambitious than many republicans like Shapiro ${ }^{20}$ in holding that we can do better than 
avoiding repression, we can indeed become free enough to identify, pursue, and secure our needs and rights. Thus, Hamilton's starting point is methodologically and substantively the opposite of Rancière's. It is empirical rather than normative, and it assumes that the radical equality in power between individuals that Rancière desires is impossible. Indeed, this is not the important question; the real question is what do we need in power terms to be free? Further, in leaving open the question of what power relations shape what groups and vice versa, Hamilton enables a broader frame of analysis than Rancière, for whom the "police" is shaped fundamentally by capitalist relations. Perhaps on Hamilton's account there is more room for critical race theorists and radical feminists to articular forms of exclusion other than the economic.

In developing his theory of "freedom is power", Hamilton argues that we individually and collectively need access to four kinds of power under modern conditions: the power to overcome individual obstacles, the power to resist social convention, the power to choose our representatives, and the power to shape the economic and social environment through our representatives. Freedom is both an individual and group problem, and as it is a group problem, shaped as these are by power relations, it necessarily involves various forms of representation. Furthermore, Hamilton invokes the aesthetic conception of representation, which implies the construction of reality through the political act rather than prior to it. Thus it is up to us to decide which accounts of groups and power relations resonate with our experiences of reality and endorse these through politics: that is: voting, engaging on social media, participating in protest, joining organizations and so on. Last, realizing freedom is a policy and institutional problem, as suggested by the idea that freedom requires the power to shape our economic and social environment through our representatives. Indeed, following Machiavelli, Hamilton holds that a key condition of freedom is the inclusion of contending groups at the heart of formal decision-making and giving them enough power to prevent tyranny or domination by one key group. While policies and institutions are not all there is to Hamilton's account of freedom is power, they are necessary to it.

A key criticism of Hamilton's account is that it lacks sufficient engagement with politics and is overly concerned with institutions, as suggested by the conclusion of Freedom Is Power (2015) where, by way of provocation, he offers some ideas for institutional reform. This has led to many to see Hamilton as falling into the "democracy as institutional reform" camp as opposed to the "democracy as disruption" camp. While this criticism is not without foundation, I think Hamilton offers more by way of a politics that links democracy as disruption to democracy as institutional reform than is commonly observed. I want to suggest that there are three elements inherent in his account that offer a basis for a more thorough account of politics that could ground practices like Robins's "slow activism." These three elements are drawn from the central role of representation to politics, the aesthetic framing of politics and the substantive political commitments implied in his four domains of freedom.

Perhaps the obvious focus and strength of Hamilton's account is a clear link, commonly made in republican accounts, between freedom and institutions. This is most clearly made in 
Hamilton's four-fold schema through the requirement to choose our representatives and to influence the wider social and economic environment through these representatives. Thus in the case of \#FeesMustFall, an awareness of the centrality of formal representatives to politics would inevitably highlight the issue of student governance on campus and, among other things, its relationship to party control. A political movement reflecting on who gets to speak for whom on what issues, including framing who the "who" is, that is, shaping political subjectivity, would have almost inevitably drawn links between student interests, student government and party capture, and the need for radical reform.

The second aspect of Hamilton's work that underpins an account of politics is his aesthetic framing of representation. Indeed, there is much in Hamilton's account of the politics of aesthetic representation and contending groups that overlaps with the forms of "disidentification," invoking of new identities, resisting social conventions, and affirmation of conflict over consensus that characterizes Rancière's account of politics. Unlike Rancière though, Hamilton has not developed this systematically and reflexively, and could pay more attention to the links between conflict, identity, and social norms and aesthetic representation than he does currently in Freedom Is Power. However, this is yet to be explicitly done, and that should not be read as denying the existence of resources for this kind of talk. It is in the conjoining of Hamilton's idea of aesthetic representation with the first two conditions of freedom is power, namely the overcoming of personal obstacles and resisting social conventions that the resources for a similar account of the symbolic dimensions of freedom of power lie.

I would suggest that implicit in Hamilton's four-fold conception of freedom is power are substantive commitments around conditions of free speech and appeals to reason and truth that inform political vision. A free society, thus, is one in which, under modern conditions, certain substantive rights must exist for individuals and groups to exercise power across Hamilton's four dimensions. The overcoming of personal obstacles implies the lack of oppressive instruments by the state (and others); the resisting of community convention implies conventional civil liberties such as freedom of thought and religion and political liberties such as free speech; the power to choose representatives assume liberties such as the right to form organizations, parties, and to vote; the power to influence economic and social environment through representatives implies debate on key policies.

Hamilton's examples of institutional reform in the conclusion make it clear that he imagines all of this as agonistic politics-that is, as democratic and requiring the use of argument but not consensus driven. A key element of this is the power of contending groups to veto the power of their rivals to oppress them. Consequently, when conjoined with a commitment to greater freedom for groups, these conditions of civil and political liberty, truth testing and rational judgment offer collective grounds for measuring political progress. The extent to which a reform enhances either the conditions for representative politics or the empowerment of key social groups in the political process is the extent to which progress toward freedom is made. This offers political movements metrics by which to define and measure reforms that enhance freedom-a resource Rancière lacks. 
Returning to the case of \#FeesMustFall, we can use the frame emergent from my reading of Hamilton to evaluate both the demands of the movement and its strategy and tactics in terms of enhancing the conditions for these progressive politics, in particular the opportunities for control by self-identifying groups to challenge what they perceive as exclusionary power relations. The issue is not just about the event, the disruption, or the riot, but also about the challenge of ongoing politics in the policy and the institutional domain of higher-education institutions. After the riot is over, will marginalized groups be able to influence politics in freedom-enhancing directions, or will there be a backlash that further excludes poor black students from higher education? Empirical research suggests that sustainable social change requires answering all these questions, and in contrast to Rancière and other advocates of democracy as disruption, Hamilton provides theoretical resources to engage with all these questions.

\section{Conclusion}

The case of the \#FeesMustFall student movement in South Africa suggests that disruption without a well-developed vision of social change runs the risk of making things worse rather than better. Hence despite its impressive gains in limiting fee increases in higher education nationally for two years in a row, and prompting institutions to reflect on the need to decolonize knowledge, \#FeesMustFall has simultaneously failed to transform the system of student representation and university governance in the higher education sector. Driven by the angry logic of spectacular politics, \#FeesMustFall has been unwilling to compromise and reluctant to negotiate. It has refused to become an organization and been incapable of building alliances with more moderate students, staff, and workers in the sector. Consequently, over the next few years the movement is likely to dwindle while university governance becomes more securitized, student representation more partisan, and university decision-making more exclusive.

Emblematic of "spectacular" versus "slow" activism more widely in South Africa, the case of \#FeesMustFall reflects the theoretical imperative to think beyond democracy as disruption, and take seriously the imperative to differentiate different kinds of "police." While Rancière's normative assumptions of radical equality flattens the "police" into one form of exclusion that does violence to the different degrees and characters of inclusion and exclusion that shape political systems around the world, Hamilton's empirical starting point of the inevitability of power relations between groups, and the importance of differentiation freedomenhancing from domineering ones, produces significantly different approaches to politics. Central here is the valorization of disruption as the only legitimate form of politics by radical theorists with little by means of further inscription contrasted with the republican view that true equality is never fully possible, and indeed chimeric to pursue. What really matters for the latter, is that we are able to escape domination and design institutions that limit the potential abuse of power.

Indeed, in this regard Hamilton is more optimistic than most republicans are, as he affirms the possibility of greater freedom through empowering individuals and groups across four 
domains to identify, pursue, and secure their needs and rights. In addition, Hamilton frames representation in the aesthetic sense of a creative act, thus affirming that group formation is not something prior to the political process, but rather is claimed and presented through the political process. This happens in the mainstream and social media, in daily life, in civil society, in elections, parliament, and in the courts. Politics is thus a power struggle between groups, but one that is constructed through political discourse and debate across society as a whole, not just in the halls of power. Lastly, against those who tend to see Hamilton as falling only or primarily into the "democracy as institutions" camp, this article argues for an account of politics drawn from three elements in Hamilton thought: the central role of representation to politics, the aesthetic framing of politics, and the substantive political commitments implied in his four domains of freedom.

In short, whether or not one agrees with Hamilton's political thought, it can provide a theoretical basis for taking seriously both political action as well as policy and institutional reform. It also suggests, returning to Norval's contrast, that democracy is nether fully about disruption nor institutional reform but some combination of both. Thus, in contrast to Rancière, who theorizes "spectacular politics" exclusively, Hamilton offers theoretical resources for a "slow activism" that includes both the riot and the policy activism and institutional representation necessary after the riot. 


\section{Notes}

1. $\quad$ Slovoj Žižek, The Ticklish Subject: The Absent Centre of Political Ontology (New York: Verso, 1999), 171.

2. Aletta Norval, "Writing a Name in the Sky': Rancière, Cavell, and the Possibility of Egalitarian Inscription," American Political Science Review 106, no. 4 (2012), 810-26.

3. Jacques Rancière, Disagreement: Politics and Philosophy (Minneapolis: University of Minnesota Press, 1999), 79.

4. Jacques Rancière, The Politics of Aesthetics (London: Continuum, 1995), 12.

5. $\quad$ Rancière, Disagreement: Politics and Philosophy, 11.

6. Rancière, Disagreement: Politics and Philosophy, 137.

7. Keith Bassett, "Rancière, Politics, and the Occupy Movement," Environment and Planning D: Society and Space 32 (2014): 886-901.

8. Ibid.

9. See Basset, "Rancière, Politics, and the Occupy Movement," 890 for the relationship of Rancière to various forms of anarchism.

10. Norval, "Writing a Name in the Sky," 810.

11. Norval, "Writing a Name in the Sky," 824.

12. Student leader 1, Former \#FeesMustFall activist and PASMA student leader, and Student Leader 2, Former \#FeesMustFall activist and EFF leader, Interviewed by Laurence Piper, February 2016.

13. Thierry Luescher and Taabo Mugume, "Student Representation and Multiparty Politics in African Higher Education," Studies in Higher Education 39, no. 3 (2014): 500-515.

14. Student leaders.

15. William A. Munro, "The Political Consequences of Local Electoral Systems: Democratic Change and the Politics of Differential Citizenship in South Africa," Comparative Politics 33, no. 3 (2001): 259-313.

16. Student leaders.

17. Steven Robins, "Slow Activism in Fast Times: Reflections on the Politics of Media Spectacles after Apartheid," Journal of Southern African Studies 40, no. 1 (2014).

18. Siyabonga Sesant, "Poo protesters' sentenced to 36 months in jail, suspended for 5 years," EWN, 19 August 2015. http://ewn.co.za/2015/o8/19/ Poo-protesters-sentenced-tojail.

19. Shamiela Fisher, "Ses'khona's nkohla sets record straight on da defection," EWN, 23 June 2016. http://ewn.co.za/2016/o6/24/Seskhonas-Nkohla-sets-the-record- straight-ondefection-to-DA.

20. Ian Shapiro, Politics against Domination (Cambridge, MA: Harvard University Press, 2016). 